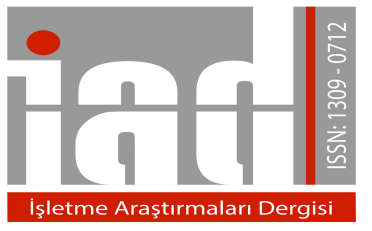

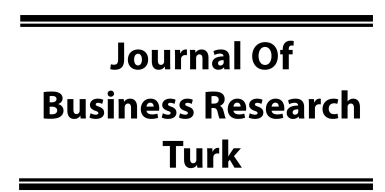

www.isarder.org

\title{
Evaluation of Customer Loyalty Implementations By Consumers
}

\author{
Ahmet UYAR \\ Afyon Kocatepe University \\ Bolvadin School of Applied Sciences \\ Department of Banking and Insurance \\ Afyon, Turkey \\ orcid.org/0000-0002-7481-4045 \\ ahmetuyar@aku.edu.tr
}

\begin{abstract}
In these times of increasing competition, customer loyalty is a concept which is critically important for businesses. Now it is more advantageous to keep existing customers rather than gaining new ones. Companies arrange various campaigns to actualise this. However, customer loyalty is not something that can be attained just by certain activities. Numerous factors such as the quality of the service provided to customers, product quality, process improvements, service speed, behaviours of company employees, etc. are critically important for customer loyalty. Within the scope of this study, consumers were asked what businesses should do to gain customer loyalty. The factors necessary for attaining customer loyalty from their perspective were listed. For this purpose, a questionnaire was administered to 300 people, and the findings obtained were subjected to variance analysis, crosstabs and correlation analyses. According to the results obtained, businesses should keep the promises they make and offer warranty for their products in order to gain customer loyalty. Consumers volunteer to do word-of-mouth marketing for those companies that meet these needs, and thus customer loyalty is ensured.
\end{abstract}

Keywords: Customer Loyalty, Levels of Customer Loyalty, Customer Loyalty Programs

\section{Introduction}

Customer is an extremely important concept for businesses. It is a force which provides businesses with income and the opportunity of survival. A customer is a person or organisation that buys or might buy the products of a certain business for personal or commercial use (Taşkın, 2000: 18).

The competition that emerged along with globalisation has significantly increased the value of customers. As a marketing specialist, Roger Blackwell described our century as the century of customers. Peter Drucker, an important name of the science of management, said it is not making sales but gaining and keeping customers that is the 
most important goal of a business. Currently, control has shifted from wholesalers and retailers to customers (Çoban, 2005: 297).

From the viewpoint of a business, the concept of customer is divided into two categories as internal and external customers. Internal customer refers to all the employees from senior managers the lowest level of personnel who perform the business activities (Çoban and Nakip, 2007: 309). The reason employees are considered as internal customers is to show the importance attached to them by the management. As one of the most important factors in the formation of product and service outputs, consideration and valuation of employees as customers is critically important for businesses. And external customers are the persons and organisations that buy for themselves or for others the products and services produced by companies (Doğan and Kıliç, 2008: 74).

The current study addresses the concept of customer loyalty and its evaluation by customers. The literature part of the research provides a definition of customer loyalty, and the advantages and methods of customer commitment. The implementation part contains consumer opinions about customer loyalty and suggests some points to consider for the success of loyalty programs performed by businesses. The results obtained offer companies some clues for providing customer commitment and create a vision for future campaigns.

\section{The Concept of Customer Loyalty}

In our times of intense commercial competition, it is rather difficult for businesses to gain customers. But it is still more difficult to keep gained ones. Customer loyalty refers to the need for companies to preserve their customers that are gained as a result of a long relationship. Kandamplly (1998: 440) saw customer loyalty as an emotional bond established with customers as a result of a high quality service. Kim and Yoon (2004: 762) defined customer loyalty as the word-of-mouth recommendation made to others by a customer who continuously prefers a business and the customer's desire to maintain this relationship with that business. Oliver (1999: 33), on the other hand, defined customer loyalty as a customer's always buying the same product despite marketing efforts that could influence customers and their persisting with the same products that they buy through their commitment to a business.

\subsection{Advantages of Customer Loyalty}

Businesses obtain many advantages thanks to customer loyalty. Especially in our times when it is more difficult and costly to keep customers than to gain them, customers provide businesses with comfort for price flexibility. Thus a business can carry out a more profitable marketing activity over a price that it likes. Besides, businesses that have loyal customers are more easily able to make their name among people through word-of-mouth and viral marketing. In this sense, they enjoy a more advantageous position in terms of advertising costs. The most important advantage of customer loyalty is about high sales figures and turnovers. As loyal customers frequently prefer the same company, such a business is not influenced by the negative fluctuations in the market and even gets over crisis periods with minimal damage. Customer loyalty also leads to internal customer satisfaction and thus enables employees to have a more reliable work environment. In this way, motivation of employees increases their belief in their business improves. As loyal customers often 
tend to share with a business their positive and negative experiences, such a company becomes able to position their future production processes more accurately.

\subsection{Levels of Customer Loyalty}

In order for businesses to recognise their customers as loyal, they needed to know the level of loyalty of each customer. There are different levels about customer loyalty.

\section{Disloyalty}

This is when a customer is not loyal and does not show commitment to the products of a business (Rowley and Dawes, 1999: 345). There can be many reasons for a customer not to be loyal to a company. Some of these are attributable to companies, and others to customers. Decreasing quality of the products or services produced by a business, the approach taken by salespersons towards customers, insufficient after-sale services, increasing prices, a company crisis, etc. are problems attributable to businesses while customers being influenced by the marketing efforts of other businesses, their beginning to like different products, their becoming more rational and beginning to make comparisons, their trying different brands out of curiosity, etc. are conditions attributable to customers.

\section{Superficial Loyalty}

Customers with superficial loyalty are those whose commitment to a company is weak although they continuously buy products from that company (Çatı and Koçoğlu, 2008: 171). They are very likely to try different brands or products as they do not have strong emotional bonds with a certain company or as they prefer a company only on a product basis. In order to keep such customers, a company needs to organise campaigns that would secure commitment by caring out research and developing various strategies (Shoemarker and Lewis, 1999: 349).

\section{Underdeveloped Loyalty}

Customers with underdeveloped loyalty do not always prefer the products of a given company although they are committed to that company and to its products with an emotional bond (Shoemarker and Lewis, 1999: 349). There are certain reasons for irregular shopping. For instance, stock-out products or a customer's decision being influenced by others around them, etc. A business should certainly examine their customers with a commitment at this extent (Selvi, 2007: 48) because such customers have the potential of becoming a loyal customer subsequently.

\section{Strong Loyalty}

This is when customers fully commit to a business and its products or services. This occurs in the form of bond establishment. Customers feeling a strong loyalty frequently buy the products of the same company (Çatı, Koçoğlu, Gelibolu, 2010: 435). According to McGoldrick and Andre (1997: 75), the reasons for the occurrence of this situation, in which errors made by a company are easily tolerated, are the following:

Laziness: A customer might prefer a certain business just because it is closer in proximity.

Habit: A customer might be regularly visiting a company just by habit. 
Comfort-Convenience: A customer might prefer a business due to such factors as parking opportunity, ease of access, time of opening, etc.

Time-Saving: There can be customers who would normally prefer other businesses but do not have time for comparison.

Fun: A customer may be satisfied with a business that they shop from and therefore they may feel an absolute commitment.

\section{Customer Loyalty Implementations}

Businesses implement various programs for securing customer loyalty. Membership cards, mobile phone messages, personal discounts, and promotions are just a few instances. Other than these, there are some creative loyalty implementations performed by companies all around the world. Examples:

- In the globally known Ritz-Carlton Hotel Company, each movement of customers is carefully followed and transferred into a special customer database. Consequently, customers receive a tailor-made service depending on their personal characteristics. As a result of this implementation that raises customer loyalty, this company has attained a significant success (Chan, Tse and Yim, 2008: 741).

- Apple Inc. forms customer groups in different states of the USA, brings them together and encourages them to exchange information. Aiming to create a special customer community by sending specific bulletins and news to these groups, the company has gained significant success in terms of customer loyalty (Metiner, 1997).

- The globally famous airline company Virgin Atlantic has performed a very successful customer loyalty implementation with its membership card. Passengers get many advantages thanks to the Virgin Atlantic flight card. The red card owners enjoy such benefits as gaining flight miles and discounts in carrental, airport parks, hotel and holiday flights, while the silver card members get $50 \%$ more points from their flights and are entitled to fast check-ins and prioritised standby flights. The golden card members, on the other hand, enjoy the benefits of double mile points, prioritised bed and seat preference, free drink and massage before flights, etc. (https://blog.hubspot.com).

- As the leading e-commerce website of the world, Amazon.com offers Amazon prime users free shipping for two days a year for $\$ 99 / y$. Due to this service, the company incurs a cost about \$1-2 million annually. As a result of this service that increases transaction volume, however, each prime member shops $\$ 1500 / y$ on average (https://blog.hubspot.com).

- Tokyo Otaku Mode is a company that sells products via the Internet. Although it was founded in 2012, it has more than 20 million followers in Facebook. The company adds a nicely designed letter of thanks, a brand-badge, a shopping bag and a memo holder with a unique illustration to the shipping package of each customer that buys a product. It also gifts 50 loyalty points to anyone who prepares and uploads a video for a product review and/or operation. With its fame in the social media spreading easily in this way, the company has reached a 


\section{A. Uyar 10/1 (2018) 143-155}

significant customer mass thanks to these creative techniques (https://www.emarsys.com).

\section{The Purpose and Importance of the Research}

The importance of customer loyalty steadily increases in our day of growing competition. It is more costly to retain existing customers than to find new ones. Therefore, companies implement various programs to keep their existing customers. The most important reason for such campaigns is to provide customer satisfaction. A consumer who is satisfied with a product they buy will want to buy more from the same brand. And this will lead to customer loyalty. Besides, a satisfied customer will enable gaining new customers by carrying out word of the mouth marketing.

The purpose of the current study is to measure the influence of customer loyalty programs on consumers. When doing this, an effort was taken to understand the evaluation of customers about various promotions and campaigns. The study also compared quality with other loyalty applications in an effort to see which one of these increase customer satisfaction more. In this regard, a questionnaire was applied to understand the influence of such demographic factors as age, gender, educational status, etc. on ensuring customer loyalty.

Previously, some relevant studies were made in connection with supermarkets, the banking industry, and tourism (Özdağoğlu, Özdağoğlu, Öz (2008), Selvi, Ercan (2006), Çat1, Koçoğlu, Gelibolu (2010), and Koçer (2017). Those studies, however, were made in specific industries and therefore their scope was limited. The current study, on the other hand, evaluates customer satisfaction applications in a general way and tries to determine the importance of loyalty programs in the minds of consumers. The most important factor for ensuring customer loyalty was also questioned within the context of the study. An effort was thus made to provide businesses with some values about which factors they should prioritise for ensuring customer loyalty.

\section{Method}

The digital data collected by the face-to-face questionnaire method for research were analysed using the SPSS 18 software package. The main audience of the research is formed by consumers. As it was not possible to reach the entire audience, sampling was utilised.

As a sampling method for the research, the "Convenience Sampling Method" was used. When determining the sample size, the sample formula used for quantitative variables and considered for populations which are unlimited or the volume of which is unknown was utilised (Özdamar, 1999: 260).

The questionnaire form was created following a literature search, reviewed based on the opinions of specialist academicians, and subjected to pilot application. Studies by Yurdakul (2007), Çatı and Koçoğlu (2008) were drawn upon when identifying the research questions, and the validity and reliability of the questionnaire was tested by a pilot administration of 40 questionnaires before finalising it.

The questionnaire form that was created based on the five-point Likert scale was administered between the dates of 20 May 2017 and 10 June 2017.

It consists of three parts. 
In the first part, participants were asked questions that were prepared by the fivepoint Likert scale about their opinions about customer loyalty.

In the second part, participants were asked questions about customer relations, for which they could indicate only one choice.

And in the third part, participants were asked about their demographic data.

In the research, 350 questionnaire forms were reached considering that there could be questionnaire forms that would be excluded due to reliability level, margin of error, deficient or erroneous coding, etc. and also considering the opportunities of the researcher for reaching the target audience. A total of 300 questionnaire forms were included in the analysis by excluding 50 questionnaire forms due to deficient or erroneous coding.

\section{Findings}

\subsection{Validity and Reliability Analysis}

In the reliability analysis, the alpha coefficient that was calculated by the internal consistency method was taken into account. The alpha coefficient is defined as the weighted standard average variation obtained by proportioning the total variances of the expression $\mathrm{k}$ contained in the scale to the general variance. The alpha coefficient is considered according to the below rating when calculating the reliability of the scale (Özdamar, 1999: 513-522).

$0.00 \leq \alpha<0.40$ The scale is not reliable,

$0.40 \leq \alpha<0.60$ Low reliability,

$0.60 \leq \alpha<0.80$ The scale is reliable,

$0.80 \leq \alpha<1.00$ The reliability of the scale is high

Table 1. Cronbach's Alpha Analysis

\begin{tabular}{|c|c|c|}
\hline \multicolumn{3}{|c|}{ Reliability Statistics } \\
\hline Cronbach's Alpha & $\begin{array}{c}\text { Cronbach's Alpha Based on } \\
\text { Standardised Items }\end{array}$ & N of Items \\
\hline, 727 &, 737 & 18 \\
\hline
\end{tabular}

According to the results of the reliability analysis, the questionnaire is included in the category of reliable questionnaires by the coefficient of 0.727 . Of the persons participating in the questionnaire, 163 are men and 137 are women. While $27 \%$ of the participants live in a metropolis, $18 \%$ live in a city centre in $46 \%$ of them live in a district. Fifty percent of the participants are university graduates, 30\% are secondary education graduates and $17 \%$ of them are primary school graduates.

\subsection{Participant Statements about Customer Loyalty}

Table 2 shows the opinions of the participants about customer loyalty. According to the table, a great majority of consumers believe that the promises which are not kept by a business will shake their confidence about that company. This is the statement agreed with by most of the consumers in the questionnaire. So, when businesses do not keep their promises, they inflict a huge damage on themselves regarding customer loyalty. According to Table 2, the statement that consumers agree with the least is the 
opinion, "I will prefer a company because of its personnel's positive attitude even if I do not like the products of the company". Other than that, the statement "A company's logo will gain loyal customers" was also a less preferred statement. Thus, product quality is regarded as more important than both company logo and also employee attitude. Employee approach alone does not suffice to gain loyal customers for a company.

Table 2. Participant Opinions about Customer Loyalty

\begin{tabular}{|c|c|c|c|}
\hline Statements & $\mathbf{N}$ & Mean & $\begin{array}{l}\text { Standard } \\
\text { Deviation }\end{array}$ \\
\hline Lifelong customer loyalty can be gained. & 300 & 3,04 & 1,163 \\
\hline $\begin{array}{l}\text { I believe that a loyal customer is prioritised by a } \\
\text { company. }\end{array}$ & 300 & 3,81 & 1,066 \\
\hline $\begin{array}{l}\text { I believe that a loyalty card (discount card) will } \\
\text { gain a company loyal customers. }\end{array}$ & 300 & 3,59 & 1,089 \\
\hline $\begin{array}{l}\text { I may become loyal to websites from which I've } \\
\text { bought a product (service). }\end{array}$ & 300 & 2,88 & 1,183 \\
\hline $\begin{array}{l}\text { Unkept promises will affect my confidence in a } \\
\text { company. }\end{array}$ & 300 & 4,36 & ,952 \\
\hline $\begin{array}{l}\text { A smiling welcome by personnel will gain loyal } \\
\text { customers. }\end{array}$ & 300 & 4,07 & ,878 \\
\hline $\begin{array}{l}\text { A company's responding messages to customers } \\
\text { will increase my commitment to that company. }\end{array}$ & 300 & 3,55 & 1,035 \\
\hline $\begin{array}{l}\text { I may prefer a company upon a recommendation by } \\
\text { an acquaintance. }\end{array}$ & 300 & 3,44 & 1,057 \\
\hline $\begin{array}{l}\text { Promotions about a company in the social media } \\
\text { will gain the company more customers. }\end{array}$ & 300 & 3,61 & 967 \\
\hline $\begin{array}{l}\text { A company's responding to the complaints and } \\
\text { requests I make over the net will increase my } \\
\text { commitment to that company. }\end{array}$ & 300 & 3,79 & ,998 \\
\hline $\begin{array}{l}\text { I will prefer a company because of its personnel's } \\
\text { positive attitude even if I do not like the products of } \\
\text { the company }\end{array}$ & 300 & 2,52 & 1,152 \\
\hline $\begin{array}{l}\text { I may remain loyal to a product due to the } \\
\text { reputation of its brand }\end{array}$ & 300 & 3,07 & 1,203 \\
\hline $\begin{array}{l}\text { I think that increasing the number of employees will } \\
\text { also increase the customer service quality. }\end{array}$ & 300 & 3,29 & 1,139 \\
\hline $\begin{array}{l}\text { Warranty provided for products will gain loyal } \\
\text { customers. }\end{array}$ & 300 & 4,09 & ,974 \\
\hline $\begin{array}{l}\text { The company which I'm loyal to will always solve } \\
\text { customer problems duly. }\end{array}$ & 300 & 3,88 & ,827 \\
\hline $\begin{array}{l}\text { I may prefer a company because I like its } \\
\text { advertisement. }\end{array}$ & 300 & 2,39 & 1,075 \\
\hline $\begin{array}{l}\text { I recommend to those around me any company that } \\
\text { I'm satisfied with it. }\end{array}$ & 300 & 4,20 & ,849 \\
\hline A company's logo will gain loyal customers. & 300 & 2,58 & 1,181 \\
\hline
\end{tabular}


In Table 3, the questionnaire participants were asked what the most important factor is for gaining customer loyalty. According to the results obtained, the most important factor that gains a company customer loyalty is reliability. Additionally, about $27 \%$ of the participants believe that the most important reason for loyalty to a company is quality. Therefore, businesses must behave reliably and market quality products to have loyal customers.

Table 3. Statements about Gaining Customer Loyalty

\begin{tabular}{|c|c|c|}
\hline What Is the Most Important Factor That Makes a Company Loyal to a Company? \\
\hline & Frequency & Percentage \\
\hline Quality & 81 & 26,9 \\
\hline Price & 31 & 10,3 \\
\hline Service & 59 & 19,6 \\
\hline Reliability & 85 & 28,2 \\
\hline Brand Value & 13 & 4,3 \\
\hline Personnel Attitude & 17 & 5,6 \\
\hline Product Diversity & 11 & 3,7 \\
\hline Other & 3 & 1,0 \\
\hline Total & 300 & 100 \\
\hline
\end{tabular}

Table 4 shows the reasons of the participants for not preferring the shopping centres that they do not like. According to the table, the participants do not prefer, in particular, those shopping centres which are expensive or do not have a sufficient service quality. The rate of those who do not prefer a shopping centre because it is expensive is around $39 \%$. So, nearly half of the participants tend to not prefer those places which they find expensive.

Table 4. Reasons for Not Preferring Shopping Centres

\begin{tabular}{|c|c|c|}
\hline \multicolumn{2}{|c|}{ What Is Your Reason for Not Preferring a Shopping Centre That You Do Not like? } \\
\hline & Frequency & Percentage \\
\hline Expensiveness & 117 & 38,9 \\
\hline Insufficient Product Diversity & 44 & 14,6 \\
\hline Negative Hearsay & 30 & 10,0 \\
\hline Insufficient Service Quality & 104 & 34,6 \\
\hline Disorderedness of Shops & 5 & 1,7 \\
\hline Total & 300 & 100 \\
\hline
\end{tabular}

Table 5 compares the age variable with the customer loyalty statement, "A company's responding messages to customers will increase my commitment to that company." According to the results obtained, as the age decreases, the importance consumers attach to responding messages increases. So, the people of advanced ages do not care responses of companies as much as the young. 
Table 5. Variance Analysis Comparing Age and Customer Loyalty

\begin{tabular}{|c|c|c|c|c|c|}
\hline Company Response to Customer & $\mathrm{N}$ & Mean & $\begin{array}{l}\text { Standard } \\
\text { Deviation }\end{array}$ & $\begin{array}{c}\text { Standard } \\
\text { Error }\end{array}$ & $\mathrm{p}$ \\
\hline $18-25$ & 129 & 3,65 & 1,036 & ,091 & \multirow[t]{6}{*}{003} \\
\hline $26-35$ & 66 & 3,79 & ,920 & ,113 & \\
\hline $36-45$ & 44 & 3,45 & 975 & 147 & \\
\hline $46-55$ & 42 & 3,29 & ,970 &, 150 & \\
\hline $55-65$ & 19 & 2,89 & 1,329 & ,305 & \\
\hline Total & 300 & 3,55 & 1,035 &, 060 & \\
\hline
\end{tabular}

Table 6 compares customer loyalty with the gender variable. According to the results, the rate of agreement with some statements differs between males and females. According to the table, compared with women, men believe more that the companies they are loyal to behave them more favourably. Women on the other hand tell that the businesses they feel customer loyalty for do not behave them differentially or specially and, compared with men, they care about company advertisements and logo more.

Table 6. T-Test Comparing Customer Loyalty with Gender

\begin{tabular}{|l|l|c|c|c|c|}
\hline & Gender & $\mathrm{N}$ & Mean & S.D. & $\mathrm{p}$ \\
\hline $\begin{array}{l}\text { I believe that a loyal customer is } \\
\text { prioritised by a company. }\end{array}$ & Men & 163 & 4,03 &, 812 & \multirow{2}{*}{, 000} \\
\cline { 2 - 5 } & Women & 137 & 3,55 & 1,260 & \\
\hline $\begin{array}{l}\text { I may prefer a company because I } \\
\text { like its advertisement. }\end{array}$ & Men & 163 & 2,27 &, 950 & \multirow{2}{*}{, 035} \\
\cline { 2 - 5 } & Women & 137 & 2,53 & 1,195 & \\
\hline $\begin{array}{l}\text { A company's logo will gain loyal } \\
\text { customers. }\end{array}$ & Men & 163 & 2,42 & 1,116 & \multirow{2}{*}{, 012} \\
\cline { 2 - 5 } $\begin{array}{l}\text { The company which I'm loyal to } \\
\text { will always solve customer } \\
\text { problems duly. }\end{array}$ & Memen & 137 & 2,77 & 1,232 & \multirow{2}{*}{, 011} \\
\cline { 2 - 5 } & Women & 137 & 3,74 &, 883 & \\
\hline
\end{tabular}

Table 7 shows of the correlation analyses comparing education level with statements about loyalty. According to the table, as the education level increases, the loyalty felt for websites also increases. Educated people appear to be prone to virtual shopping and they feel more commitment to websites. Again, according to Table 7, a positive and slightly significant relationship exists between education level and the importance attached to company responses. Educated people care more for company responses to customers, and they state that they will have more commitment to those businesses which behave like that. According to the third correlation in the table, as the education level increases, the rate of having recommendations from others decreases. There is a negative and slightly significant relationship between the two. So, it appears that educated people get less recommendation about companies. 
Table 7. Correlation Analysis Comparing Educational Level and Loyalty Statements

\begin{tabular}{|c|c|c|c|c|}
\hline & & $\begin{array}{l}\text { I may become } \\
\text { loyal to websites } \\
\text { from which I've } \\
\text { bought a product } \\
\text { (service). }\end{array}$ & $\begin{array}{l}\text { A company's } \\
\text { responding } \\
\text { messages to } \\
\text { customers will } \\
\text { increase my } \\
\text { commitment to } \\
\text { that company. }\end{array}$ & $\begin{array}{l}\text { I may prefer a } \\
\text { company upon a } \\
\text { recommendation } \\
\text { by an } \\
\text { acquaintance. }\end{array}$ \\
\hline \multirow{3}{*}{$\begin{array}{l}\text { Education } \\
\text { Level }\end{array}$} & Pearson Correlation &, $139^{*}$ &, $133^{*}$ &,$- 182^{* *}$ \\
\hline & Sig. (2-tailed) & ,028 &, 035 &, 004 \\
\hline & $\mathrm{N}$ & 300 & 300 & 300 \\
\hline
\end{tabular}

Correlation is significant at the 0.05 level (2-tailed).

\section{Conclusion}

In the current trade environment, customer loyalty is one of the most important concepts for businesses. There are numerous variables which attract consumers to different brands and products. In such an intense competitive environment, it is rather difficult to maintain long-term customer relationships. In recent years, companies use many different marketing techniques to cope with this difficulty.

The current study examined the consumer perspectives about customer loyalty and related applications. According to the findings, consumers expect companies to keep their promises. Failure to do this will have a significant impact on customer loyalty. Consumers tend to recommend the companies they like to others by word-ofmouth marketing. The fact that the communication environment is very advanced on our day has popularised viral marketing.

Consumers believe that a company's logo and its advertisements are not sufficient for ensuring customer loyalty. A good promotion strategy may bring brand awareness but it does not appear possible for this alone to commit customers to the business and establish a long-term relationship environment. Therefore, a company with an insufficient quality of goods and services is very unlikely to succeed in terms of customer loyalty. Businesses must keep the added value that consumers acquire from products high. For this reason, it is important that the sale department analyses customer value and total quality issues well.

When the questionnaire participants were asked what the most important factor for getting customer loyalty, such concepts as reliability, quality, smiling, etc. are highlighted. Customers prefer reliable companies and high-quality products and they believe that this is the only way for establishing long-term customer relationships. Employees' behaving with good humour and establishing good relationships also count in establishing customer loyalty. From this perspective, relational marketing should be designed properly and this should be supported by quality products and services. Companies should not make promises which they would not be able to keep. Consumers prioritise company honesty highly in terms of customer loyalty.

When the comparative tables in the study are analysed, it appears that the young people care more for responses coming from companies. When this age group, which is called the Generation Z, demands something from a business, they expect it to be met 
rapidly. It can thus be said that the young are more demanding. In recent years, the increasing value given to customers and the raising importance of the concept of customer orientation has been increasing consumer expectations each passing day.

There appear to be some gender-based differences about customer loyalty. According to the t-test contained in the study, men seem to be more satisfied with the businesses they feel loyalty for. Women, on the other hand, when compared with men, believe that the companies they are loyal to do not behave them sufficiently well and that they remain insufficient in problem-solving. It was also observed that women care more for such marketing elements as advertisements and logos. Thus, messages that could attract the attention of men more should be provided in advertisements.

According to the correlation analysis included in the study, the influence of wordof-mouth marketing increases as the education level decreases. Highly educated people tend to act based on their own opinions when buying products. They are also more confident about shopping via the Internet and feel more loyal to websites. They expect companies to respond to them and believe that their demands and requests they make in different times must not be ignored.

The study showed that customer loyalty is especially closely related with the concept of confidence. After-sale services, warranty, keeping of promises and quality are elements that determine customer loyalty. All the activities of a business from the identification of raw material, which is the first stage of the supply chain, to the usage of products by customers and even to the stage of collecting customer information should be planned according to customer requests. As regards those companies which want to establish long-term customer relationships, it will be determining for their futures and their relationships with customers to take these into consideration, ensure customer satisfaction, and display a customer oriented approach. 


\section{References}

Bernazzi, S. (2017). Customer Loyalty: The Ultimate Guide. https://blog.hubspot.com /blog/tabid/6307/bid/31990/7-Customer-Loyalty-Programs-That-Actually-AddValue.aspx\#sm.00015rnwlk9tddnoz5o119hrhz8ul

Chan, K, W., Tse D, K, and Yim C, K, (2008). "Strengthening Customer Loyalty Through Intimacy and Passion: Roles of Customer-Firm Affection and Customer-Staff Relationships in Services" Journal of Marketing Research. Vol. XLV, 741-775.

Çatı, K. and Koçoğlu, C. M., Gelibolu L. (2010). "Müşteri Beklentileri İle Müşteri Sadakati Arasındaki İlişki: Beş Yıldızlı Bir Otel Örneği” Ç.Ü. Sosyal Bilimler Enstitüsü Dergisi, Cilt.19, Sayı.1, 429-446.

Çatı, K. and Koçoğlu, C. M. (2008). "Müşteri Sadakati ile Müşteri Tatmini Arasındaki İlişkiyi Belirlemeye Yönelik Bir Araştırma” Selçuk Üniversitesi Sosyal Bilimler Enstitüsü Dergisi, Cilt.19, Sayı.1, 171.

Çoban S. and Nakip M. (2007) Yıldırma (Mobbing) "Olgusunun İçsel Pazarlama İle İlişkisi: Nevşehir'de Bulunan Bankalar Örneği” Atatürk Üniversitesi İktisadi and İdari Bilimler Dergisi, Cilt. 21, Say1.1, 307-320.

Çoban S. (2005). "Müşteri Sadâkatinin Kazanılmasında Veri tabanlı Pazarlamanın Kullanımı" Erciyes Üniversitesi Sosyal Bilimler Enstitüsü Dergisi, Cilt. 1, Sayı.19, 297.

Doğan S. and Kılıç S., (2008). "İlişki Yönetiminde İç and Dış Müşteri Memnuniyetinin Sağlanması" Karamanoğlu Mehmet Bey Üniversitesi İIBF Dergisi, Cilt.10 Sayı.14, 6087.

Garai T. (2017). 3 Examples Of Customer Loyalty Programs Fueled By Data. https:// www.emarsys.com/en-sg/resources/blog/3-loyalty-program-examples-customerdata/

Koçer, K. (2017). "Müşteri İlişkileri Yönetiminin Müşteri Sadakati Üzerine Etkisi: Bankacılık Sektörü Üzerine Bir Alan Araştırması" Karabük Üniversitesi Sosyal Bilimler Enstitüsü Dergisi” Cilt. 7, Sayı. 2, ss. 713-735.

Kandampully, J. (2001). Service Quality to Service Loyalty Managament. McKinsey \& Co.

Kim, H. S, \& Yoon, C. H., (2004). "Determinants of Subscriber Churn and Customer Loyalty in the Korean Mobile Telephony Market", Telecommunication Policy, Vol: 28. Republic of Korea: Elsevier Ltd.

McGoldrick, P. J. and E. Andre (1997). "Consumer Misbehaviour-Promiscuity or Loyalty in Grocery Shopping?" Journal of Retailing and Consumer Services, Vol.4, No.2, 73-81.

Metiner H. (1997). "İşletmede Müşteri Sadakatini arttırmaya Yönelik Programlar and Sadakat Programlarının Etkinliğinin Ölçülmesi Üzerine Bir Araştırma Önerisi,” (Basılmamış Yüksek Lisans Tezi, İstanbul Üniversitesi Sosyal Bilimler Enstitüsü) İstanbul. 
Rowley, J and Jillian D. (1999). "Customer Loyalty: A Relative Consept for Libraries" Library Management, Vol.2, No.6, 345-351.

Selvi, M.S, (2007). Müşteri Sadakati. Detay Yayıncılık, Ankara.

Selvi, M.S. ve Ercan, F. (2006). "Otel İşletmelerinde Müşteri Sadakatinin Değerlendirilmesi: İstanbul'daki Beş Yıldızlı Otel İşletmelerinde Bir Uygulama" Balıkesir Üniversitesi Sosyal Bilimler Enstitüsü Dergisi, Cilt. 9, Sayı.15, ss. 159188.

Shoemaker, S. and Lewis, R. C. (1999). "Customer Loyalty: The Future of Hospitality Marketing" International Journal of Hospitality Management, Vol.18, No.4, 345370.

Oliver, R. (1999). “Whence Consumer Loyalty?” Journal of Marketing, Cilt.63, 33-44.

Özdamar, K., (1999). SPSS ile Biyoistatistik (3. Bask1). Kaan Kitabevi, Eskişehir.

Özdağoğlu, A., Özdağoğlu G., ve Öz, E. (2008). "Müşteri Sadakatinin Sağlanmasında Müşteri İlişkileri Yönetiminin Önemi: İzmir'de Bir Hipermarket Araştırması" Atatürk Üniversitesi İktisadi ve İdari Bilimler Dergisi, Cilt 22, Sayı 1, 367-380

Yurdakul, M. (2007). "İlişkisel Pazarlama Anlayışında Müşteri Sadakati Olgusunun Ayrıntılı Bir Şekilde Analizi”, Dumlupınar Üniversitesi Sosyal Bilimler Enstitüsü Dergisi, Say1.17, 268-287.

Taşkın, E., (2000). Müşteri İlişkileri Eğitimi, Papatya Yayıncılık, İstanbul. 